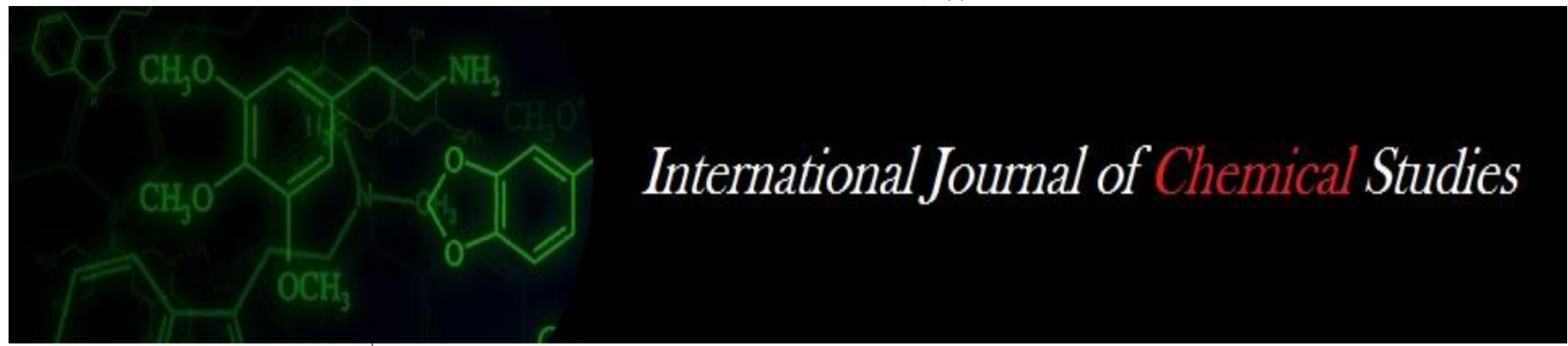

P-ISSN: 2349-8528

E-ISSN: 2321-4902

www.chemijournal.com

IJCS 2021; 9(1): 481-483

(C) 2021 IJCS

Received: 16-10-2020

Accepted: 24-11-2020

Dawale MB

Department of Plant Pathology,

College of Agriculture, Dr.

Balasaheb Sawant Konkan

Krishi Vidyapeeth, Dapoli,

Maharashtra, India

Borkar PG

Department of Plant Pathology, College of Agriculture, Dr.

Balasaheb Sawant Konkan

Krishi Vidyapeeth, Dapoli,

Maharashtra, India

Joshi MS

Department of Plant Pathology,

College of Agriculture, Dr.

Balasaheb Sawant Konkan

Krishi Vidyapeeth, Dapoli,

Maharashtra, India

\section{Potphode PD}

Department of Plant Pathology, College of Horticulture, Mulade,

Dr. Balasaheb Sawant Konkan

Krishi Vidyapeeth, Dapoli,

Maharashtra, India

\section{UB Pethe}

Department of Agricultural Botany, College of Agriculture, Dr. Balasaheb Sawant Konkan Krishi Vidyapeeth, Dapoli, Maharashtra, India

Corresponding Author: Dawale MB

Department of Plant Pathology,

College of Agriculture, Dr.

Balasaheb Sawant Konkan

Krishi Vidyapeeth, Dapoli,

Maharashtra, India

\section{In-vitro evaluation of fungicides against Cylindrocladium spp causing defoliation and die- back in Cashew}

\author{
Dawale MB, Borkar PG, Joshi MS, Potphode PD and UB Pethe
}

DOI: https://doi.org/10.22271/chemi.2021.v9.i1g.11276

\begin{abstract}
Among all the 10 fungicides/ fungicide combinations under study, complete inhibition of the mycelial growth occurred in mancozeb $(0.00 \mathrm{~mm})$ and metalaxyl in combination with mancozeb. They were followed by zineb plus hexaconazole $(12 \mathrm{~mm})$, Chlorothalonil $(12.33 \mathrm{~mm})$, carbendazim $(15.67 \mathrm{~mm})$, Zineb $(17.33 \mathrm{~mm})$, Hexaconazole $(17.67 \mathrm{~mm})$, thiophenate methyl $(18.00 \mathrm{~mm})$, copper oxy-chloride $(26.00 \mathrm{~mm})$ and copper hydroxide $(27.00 \mathrm{~mm})$ respectively. Maximum growth $(90.00 \mathrm{~mm})$ was recorded in control.
\end{abstract}

Keywords: Fungicides, Cylindrocladium spp.

\section{Introduction}

Anacardium occidentale L. belonging to the family Anacardiaceae is a native to Brazil and was introduced to India five centuries ago (Shanthi and Vittal, 2012) ${ }^{[10]}$. In India cashew is being grown on an area of 10.27 lakh hectares with a total production of 7.25 lakh MT of raw nuts and productivity of $706 \mathrm{~kg} / \mathrm{ha}$. India is the largest producer of raw cashewnut contributing 20 per cent of total global production. In India, Maharashtra ranks first in production and productivity of cashew with an average annual yield of $1262 \mathrm{Kg} / \mathrm{ha}$ (Anonymous, 2019) ${ }^{[1]}$.

Cashew is not only a delicious and nutritious but is also a hardy and highly remunerative crop owing to its minimal crop management requirements. Cashew being tropical crop can tolerate higher temperatures but is highly sensitive to frost. The optimum temperature range for successful cultivation is about 20 to $30{ }^{\circ} \mathrm{C}$. The annual precipitation of 1000 to $2000 \mathrm{~mm}$ is ideal for cashew. Coincidence of flowering with high rain fall or excess humidity leads to incidence of pests and diseases (Bhoomika and Sudha Rani, 2018) ${ }^{[2]}$.

Incessant prolonged rain showers coupled with more than 90 per cent humidity during the monsoon season of 2019, resulted in occurrence and quick spread of defoliation followed by die-back in all the cashew pockets along the length and breadth of Konkan region. This situation alarmed an urgent study of the malady to solace the cashew growers with an appropriate and affordable solution to the problem. Therefore; the present investigation was carried out to test different fungicides against Cylindrocladium spp. under laboratory conditions.

\section{Material and Methods}

Fungicides reported effective against Cylindrocladium spp. causing various diseases in different horticultural and agronomical crops, were evaluated in vitro by applying Poisoned Food Technique (Nene and Thapliyal, 1993) ${ }^{[7]}$ and using Potato Dextrose Agar as basal medium. The experiment was planned to evaluate in vitro efficacy of ten fungicides including systemic, contact and combination product fungicides against the pathogen.

The efficacy of fungicides was expressed as per cent inhibition of mycelial growth as compared to control and was calculated by using the formula given by Vincent (1927) ${ }^{[13]}$. The data obtained were averaged and analyzed statistically.

Per cent Inhibition $(\mathrm{I})=\frac{\mathrm{C}-\mathrm{T}}{\mathrm{C}} \times 100$ 


\section{Where}

$\mathrm{I}=$ Per cent inhibition

$\mathrm{C}=$ Growth $(\mathrm{cm})$ of the pathogen in control plate.

$\mathrm{T}=$ Growth $(\mathrm{cm})$ in treatment

\section{Results}

In this study, ten fungicides were evaluated in vitro to judge their efficacy against Cylindrocladium spp by poisoned food technique. It was revealed from the data that the effect of different fungicides on growth of Cylindrocladium spp was significant. The observations on mycelial growth and per cent inhibition of mycelium were recorded. The results are presented in table 1 .

Table 1: In vitro evaluation of different fungicides against Cylindrocladium spp

\begin{tabular}{|c|c|c|c|c|}
\hline Tr. No. & Treatments & Concentration \% & Mean Colony Diameter (mm)* Per cent inhibition compared to control \\
\hline T1 & Carbendazim 50\% WP & $0.1 \%$ & 15.67 & 82.58 \\
\hline T2 & Thiophenate methyl 70\% WP & $0.1 \%$ & 18.00 & 80.00 \\
\hline T3 & Chlorothalonil 75\% WP & $0.2 \%$ & 12.33 & 86.20 \\
\hline T4 & Zineb 78\% WP & $0.25 \%$ & 17.33 & 80.74 \\
\hline T5 & Mancozeb 75\% WP & $0.25 \%$ & 00.00 & 700 \\
\hline T6 & Copper oxychloride 50\% WP & $0.25 \%$ & 26.00 & 71.11 \\
\hline T7 & Copper hydroxide 77\% WP & $0.2 \%$ & 27.00 & 80.00 \\
\hline T8 & Hexaconazole 5\% SC & $0.1 \%$ & 17.67 & 86.66 \\
\hline T9 & Zineb 68\% WP + Hexaconazole 4\% WP & $0.2 \%$ & 12.00 & 100 \\
\hline T10 & Metalaxyl 4\% WP + Mancozeb 64\% WP & $0.2 \%$ & 00.00 & - \\
\hline T11 & Control & - & 90.00 & - \\
\hline & S.E.m \pm & - & 0.036 & 0.107 \\
\hline
\end{tabular}

* Mean of three replications

Perusal of data presented in Table -1 revealed that the effect of fungicides on growth of Cylindrocladium spp was significant. Among all the 10 fungicides/fungicide combinations under study, complete inhibition of the mycelial growth occurred in mancozeb $(0.00 \mathrm{~mm})$ and metalaxyl in combination with mancozeb. They were followed by zineb plus hexaconazole $(12 \mathrm{~mm})$, Chlorothalonil (12.33mm), carbendazim $(15.67 \mathrm{~mm})$, zineb $(17.33 \mathrm{~mm})$, hexaconazole $(17.67 \mathrm{~mm})$, thiophenate methyl $(18.00 \mathrm{~mm})$, copper oxychloride $(26.00 \mathrm{~mm})$ and copper hydroxide $(27.00 \mathrm{~mm})$ respectively. Maximum growth $(90.00 \mathrm{~mm})$ was recorded in control.

\section{Discussion}

The in vitro studies conducted to evaluate 10 fungicides/ fungicide combination against the pathogen Cylindrocladium spp revealed that, manconcozeb 75 WP completely inhibited the mycelial growth of the pathogen. So also, the combination fungicide comprising metalaxyl 4\% WP plus mancozeb $64 \%$ WP exhibited similar results. Carbendazim ranked fourth in order of merit with $15.67 \mathrm{~mm}$ growth and 82.58 per cent inhibition as compared to control.

Sulochana (1980) [12] achieved the best results with carbendazim at the least concentration $(250 \mathrm{ppm})$ and further higher concentrations. Mancozeb was also effective but at higher concentration of $1000 \mathrm{ppm}$ and above. Her results in respect of mancozeb are at par with results of present study but contradictory in respect of carbendazim.

Sharma and Mohanan (1991) [11] while working on five species of Cylindrocladium found that among the 22 fungicides tested in vitro, only carbendazim provided complete inhibition.

Jayasinghe and Wijesundera (1995) ${ }^{[5]}$, found that benomyl, mancozeb, metalaxyl $8 \%$ plus mancozeb $64 \%$ and oxadixyl $10 \%$ plus mancozeb 56\%, were effective against Cylindrocladium quinqueseptatum. The findings of this study are at similitude with present results in respect of sole mancozeb and its combination with metalaxyl.

It was also reported by Polizzi and Vitale (2001) ${ }^{[8]}$ that, mycelial growth of six strains of $C$. pauciramosa was completely inhibited by carbendazim at $1000 \mathrm{ppm}$ concentration.

Similarly, Henricot, et al. (2008) ${ }^{[4]}$ found that, out of 13 fungicides evaluated against Cylindrocladium, carbendazim at 5000 ppm concentration completely inhibited mycelial growth of the pathogen.

Mancozeb both at 500 and 1000 ppm concentration completely inhibited mycelial growth of Cylindrocladium jatrophae (Chavan et al., 2011).

The results of Safrankova et al. (2013) ${ }^{[9]}$ points out that mycelial growth and conidial germination of $C$. buxicola were inhibited up to 96 per cent by mancozeb.

The results of present study are in accordance with those of Chavan et al. (2011) and Safrankova et al. (2013) ${ }^{[9]}$.

Among the six fungicides tested against $C$. quinqueseptatum the pathogen of leaf blight of clove; Khare et al. (2014) ${ }^{[6]}$ found that, the growth as well as sporulation of the pathogen was absolutely inhibited by carbendazim and carbendazim plus mancozeb. These findings are contrary to current findings in respect of carbendazim.

\section{References}

1. Anonymous. Production scenario of Cashew Directorate of cashewnut and cocoa development 2019.

2. Bhoomika HR, Sudha Rani N. Problems and Prospects of Cashew Cultivation in India - An Overview. Int. J. Curr. Microbiol. App. Sci 2018;7(10):3687-3694.

3. Chavhan TL, Suryanarayana V, Naik ST. Evaluation of Fungicides, Botanicals and Bioagents against Cylindrocladium jatrophae causing white mold of Jatropha curcas L. Crop Prot 2011;44:1-5.

4. Henricot B, Gorton C, Denton G, Denton J. Studies on the control of Cylindrocladium buxicola using fungicides and host resistance. Plant Dis 2008;92:1273-1279.

5. Jayasinghe CK, Wijesundera RLC. In vitro evaluation of fungicides against clove isolate of Cylindrocladium quinqueseptatum in Sri Lanka. International Journal of Pest Management 1995;41(4):219-223.

6. Khare J, Borkar PG, Navathe S. Investigations on Leaf Blight Disease of Clove Incited by Cylindrocladium 
quinqueseptatum Boedijn \& Reitsma. World J. Agric. Res 2014;2(6):272-275.

7. Nene YL, Thapliyal RN. Fungicides in Plant Disease Control (3rd Ed.).Oxford, IBH Pub. Co., New Delhi 1993,331p.

8. Polizzi G, Vitale A. First report of the prevalence of benzimidazole-resistant isolates in a population of Cylindrocladium pauciramosum in Italy. Plant Disease 2001a;85:1210.

9. Safrankova I, Holkova L, Kmoch M. Leaf spot and dieback of Buxus caused by Cylindrocladium buxicola. Plant Prot. Sci 2013;49:165-168.

10. Shanthi S, Vittal BPR. Fungal diversity and the pattern of fungal colonization of Anacardium occidentale leaf litter. Mycology 2012;3(2):132-146.

11. Sharma JK, Mohanan C. In vitro evaluation of fungicides against Cylindrocladium spp. causing diseases of Eucalyptus in Kerala, India1. European Journal of Forest Pathology 1991;21:17-26.

12. Sulochana KK. Studies on the leaf blight disease of clove caused by Cylindrocladium sp. Msc thesis. Department of Plant Pathology, College of Agriculture, Vellayani. KAU 1980.

13. Vincent JM. Distortion of fungal hyphae in presence of certain inhibitors. Nature 1927;159:850. 